UDC 330.1:378.1:658

JEL Classification: O35; 123; C31

\title{
TRANSFORMATION OF THE INTERACTION BETWEEN THE EDUCATIONAL AND SCIENTIFIC ACTIVITY OF A UNIVERSITY IN THE INNOVATIVE ECONOMY
}

\author{
${ }^{\circledR 2021}$ RAYEVNYEVA O. V., OSTAPENKO V. M.
}

UDC 330.1:378.1:658

JEL Classification: 035; 123; C31

\author{
Rayevnyeva O. V., Ostapenko V. M. \\ Transformation of the Interaction between the Educational and Scientific Activity \\ of a University in the Innovative Economy
}

The article aims at studying the technology of transforming the interaction between the educational and scientific activity of a university taking into account the innovative model of economic development, which involves determining the stages of university transformation, while putting emphasis on peculiarities of R\&D activity, interaction between the educational and scientific activity, and elements of their control system. The article identifies the factors determining the need for transformation of research and development and innovative activities, and the main areas of transforming research in Ukraine. The algorithm for transforming the interaction between the educational and scientific activity of a university is formed, consisting of individual but interconnected elements, such as legislative and statutory support in the educational and R\&D activity; interaction between the educational and R\&D activity of a university; management of the interaction between the educational and R\&D activity of a university. Problems and priority areas in the work of the state policy carried out by the Ministry of Education and Science of Ukraine are highlighted. A number of legislative initiatives of the Ministry, launched in 2020 and planned for the future, have been approved in order to solve the existing problems in these areas. The Ministry of Education and Science has implemented and planned activities aimed at stimulating transformations in education, science and innovation. Legislative and regulatory support in the educational and $R \& D$ areas is grouped according to the stages of its adoption. The most common models used at modern universities are characterized in accordance with their peculiarities in combining R\&D and educational activities of a university, its structural units and individual faculty members. Specific features of managing of $R \& D$ activity at a research (entrepreneurial, innovative) and educational universities are compared. The interaction areas of interaction between educational and scientific transformations in Ukraine that could influence its scientific development and promote its integration into the European Research Area are highlighted.

Keywords: R\&D activity, university, transformation, higher education, state policy of the Ministry of Education and Science, interaction between the educational and R\&D activity, research (entrepreneurial, innovative) university.

DOI: https:// doi.org/10.32983/2222-0712-2021-4-67-78

Рис.: 5. Табл.: 6. Формул: 5. Бібл.: 17.

Rayevnyeva Olena V. - Doctor of Sciences (Economics), Professor, Head of the Department of Statistics and Economic Forecasting, Simon Kuznets Kharkiv National University of Economics (9a Nauky Ave., Kharkiv, 61166, Ukraine)

E-mail: olena.raev@gmail.com

ORCID: http://orcid.org/0000-0003-0260-4249

Researcher ID: https://publons.com/researcher/1660647/olena-rayevnyeva/

Scopus Author ID: https://www.scopus.com/authid/detail.uri?authorld=56669948000

Ostapenko Viktoriia M. - Candidate of Sciences (Economics), Associate Professor, Associate Professor of the Department of Customs, Simon Kuznets Kharkiv National University of Economics (9a Nauky Ave., Kharkiv, 61166, Ukraine)

E-mail: viktoria.ostapenko@hneu.net

ORCID: http://orcid.org/0000-0002-4077-5738

Researcher ID: https://publons.com/researcher/2155535/viktoriia-ostapenko/

Scopus Author ID: https://www.scopus.com/authid/detail.uri?authorld=57202383896

УДК 330.1:378.1:658

JEL Classification: 035; 123; C31

Раєвнєва О. В., Остапенко В. М. Трансформація взаємодії освітньої та наукової діяльності університету в інноваційній економіці

Метою статті є дослідження технології трансформації взаємодії освітньої та наукової діяльності університету з урахуванням інноваційної моделі економічного розвитку, що передбачає визначення етапів трансформації університету з акцентами й особливостями науково-технічної діяльності, взаємодії навчальної та наукової діяльності та елементів системи управління ними. У статті визначено фактори, які обумовлюють необхідність трансформації науково-технічної та інноваційної діяльності й основні напрями наукових трансформацій в Україні. Сформовано процес

"Comprised within applied research topic No 46 / 2020-2021 «Development of methodological and modelling and information support for constructing an innovative university on the basis of quality education and fight against corruption» 
трансформації взаємодії освітньої та наукової діяльності університету, який складається з окремих взаємопов'язаних елементів: законодавчонормативного забезпечення у сфері освітньої та науково-технічної діяльності; взаємодії освітньої та науково-технічної діяльності університету; управління взаємодією освітньої та науково-технологічної діяльності університету. Відокремлено проблеми та пріоритетні напрями державної політики МОН України. 3 метою розв'язання наявних у цих сферах проблем ухвалено низку нормотворчих ініціатив Міністерства, започаткованих у 2020 році і запланованих на майбутнє. МОН реалізовано та заплановано заходи, що мають на меті транссормаційні процеси у сфері освіти, науки та інновацій. Згруповано законодавчо-нормативне забезпечення в освітній та науково-технічній сферах за стадіями затвердження. Охарактеризовано найбільш поширені в сучасних університетах моделі відповідно до особливостей поєднання науково-технічної й освітньої діяльності університету, його структурних підрозділів та окремих викладачів. Здійснено порівняння особливостей управління науково-технічною діяльністю у дослідницькому (підприємницькому, інноваційному) та навчальному університетах. Виділено напрями взаємодії освітніх і наукових транссормацій в Україні, що справлятимуть вплив на розвиток науки, а також сприятимуть інтеграції до Європейського дослідницького простору.

Ключові слова: науково-технічна діяльність, університет, трансформачія, вища освіта, дернавна політика Мон, взаємодія освітньої та науковотехнічної діяльності, дослідницький (підприємницький, інноваційний) університет.

Рис.: 5. Табл.: 6. Бібл.: 17.

Раєвнєва Олена Валентинівна - доктор економічних наук, професор, завідувач кафедри статистики і економічного прогнозування, Харківський національний економічний університет ім. С. Кузнеця (просп. Науки, 9а, Харків, 61166, україна)

E-mail: olena.raev@gmail.com

ORCID: http://orcid.org/0000-0003-0260-4249

Researcher ID: https://publons.com/researcher/1660647/olena-rayevnyeva/

Scopus Author ID: https://www.scopus.com/authid/detail.uri?authorld=56669948000

Остапенко Вікторія Миколаївна - кандидат економічних наук, доцент, доцент кафедри митної справи, Харківський національний економічний університет ім. С. Кузнеця (просп. Науки, 9а, Харків, 61166, Україна)

E-mail: viktoria.ostapenko@hneu.net

ORCID: http://orcid.org/0000-0002-4077-5738

Researcher ID: https://publons.com/researcher/2155535/viktoriia-ostapenko/

Scopus Author ID: https://www.scopus.com/authid/detail.uri?authorld=57202383896

Introduction. Strengthening the integration of higher education, science and innovative economic activity will provide their compliance with the real needs of the private and public sectors of the national economy. The combination of education and science is a basis for the education system modernization and the main factor for further development of innovative educational activities of the university. Strengthening the link between educational, scientific and innovative components in the system will solve the problems that occur while carrying out a structural reform in the economy, creating new knowledge-intensive innovative industries, and intensifying entrepreneurship.

Research analysis and problem statement. In Ukraine, the problems of transforming educational and scientific activities at the university are conditioned by research and publications in various areas of state regulation, such as humanitarian educational paradigm (D. Bell, E. Denison, I. Kolesnikova, N. Romaeva, I. Fomichova, E. Shiyanova, E. Yamburg), and determining the impact on the implementation of social and economic priorities for society (W. Berquist, M. Baumen, I. Bertrand, B. Zueva, J. M. Keynes, Y. Kuzminova, A. Subetto, B. M. Filipova, L. Jacobson, E. Toffler, D. Wheeler, T. Schultz). However, there is a need for studying transformations in educational and scientific activities at a university, e.g. in definitions, purposes and priorities for gaining educational and scientific achievements in certain conditions of the innovative model of national economy.

The aim of the article is to study technological instruments for transforming educational and scientific activities at the university according to the innovative model of economic development, which involves determining the stages of transformation of the university according to the peculiarities and features of scientific activity, its interaction with educational activity, and elements of their management.

Results. The state regulation of education and science is the basis for ensuring human capital development and providing an opportunity to obtain economic benefits, which would provide for Ukraine's sustainable growth and competitive economy. According to Sustainable Development Goals, there is a need for using «innovative technologies», «innovative approaches» [13] and transforming scientific, technological and innovative activities, because their use, happening due to a number of factors, would correspond to both the European and global trends (Fig. 1).

The transformation of scientific activities is a priority ensuring social, economic, political and scientific development in many countries of the world. In terms of integration into the world and European scientific environment, the current stage of Ukraine's development is characterized by systemic and radical transformations. The strategic task of the integration process should take into account the peculiarities of national identity and should not be accompanied by the leveling of its own national educational system. The main areas of scientific and technological transformations are presented in fig. 2. To develop science and innovation, it is necessary to transform Ukrainian science by implementing innovative approaches and methods, and providing universities and scientists with opportunities and resources to conduct research that would positively affect Ukraine's socio-economic and innovative development. The education and science must become a lever of social equality 
Factors that determine the need for scientific and technological transformation and innovation

\begin{tabular}{|c|c|c|c|c|}
\hline $\begin{array}{c}\text { Necessity to update the } \\
\text { priorities of science, } \\
\text { technology and innovation } \\
\text { (previous list has expired) }\end{array}$ & $\begin{array}{c}\text { The existing priorities } \\
\text { do not reflect the } \\
\text { economic and scientific } \\
\text { state of the country }\end{array}$ & $\begin{array}{c}\text { Priorities must be combined } \\
\text { and ensure an unbroken chain } \\
\text { from idea to implementation } \\
\text { in the economy }\end{array}$ & $\begin{array}{c}\text { The choice of } \\
\text { priorities is to } \\
\text { determine the } \\
\text { state innovation }\end{array}$ \\
\hline
\end{tabular}

Fig. 1. Factors that determine the need for transforming scientific and innovative activities

and cohesion in society, a trigger for Ukraine's economic development and competitiveness in the world.

Thus, the higher education system must create new conditions for obtaining modern knowledge, solving complex problems, creating high-quality and innovative intellectual products. At present, education in Ukraine does not meet modern needs of the individuals and society, that is the requirements of the economy and global trends. Therefore, a systemic transformation in education, science and innovation is needed in order to ensure the appropriate quality of education. The reforms in science and technology will stop stagnation in research, generate demand for qualitative developments and training, reduce inconsistencies between research and implementation of its results, integrate them into the educational and research space of the EU.

The process of transforming educational and scientific activities at a university consists of individual interconnected elements. The technology of transforming educational and scientific activities at a university comprises the following elements:

- legislative and regulatory support for scientific activity;

- organization of educational and scientific activities at a university;

- interaction between educational and scientific activities at a university;

- management of educational and scientific activities at a university.

Legislative and regulatory support regulating educational and scientific activities comprises two framework laws and a number of regulations governing certain aspects of these activities. To solve the existing problems in these areas, many regulatory initiatives of the Ministry were launched in 2020 and are planned for the future (Table 1) [5].

Formation of legislative and regulatory support in educational and scientific activities [5]

\begin{tabular}{|c|c|}
\hline $\begin{array}{l}\text { Stages of } \\
\text { approval }\end{array}$ & Legislative and regulatory support \\
\hline 1 & 2 \\
\hline Approved & $\begin{array}{l}\text { - Law "On amendments to some laws of Ukraine on the intensification of science parks" [10]; } \\
\text { - Order of the Cabinet of Ministers of Ukraine (CMU) "On changing the composition of the National Council for the } \\
\text { Development of Science and Technology" [11]; } \\
\text { - Resolution of the CMU "On Amendments to the Regulations on the National Council of Ukraine for the } \\
\text { Development of Science and Technology" [7]; } \\
\text { - Resolution of the CMU "On Amendments to the Procedure for Formation and Use of Funds of the National } \\
\text { Research Fund of Ukraine" [8]; } \\
\text { - Resolution of the CMU "On Amendments to the Resolutions of CMU of July 4, } 2018 \text { № } 528 \text { and of December 4, } \\
2019 \text { № } 1007 \text { " [9] }\end{array}$ \\
\hline Prepared & $\begin{array}{l}\text { - Draft Law "On Amendments to Certain Laws of Ukraine on Stimulating Activities in the Sphere of Technology } \\
\text { Transfer", the purpose of which is to increase the level of implementation (commercialization) of research results; } \\
\text { - Orders of the CMU "On approval of the Concept of the state program of development of research infrastructures in } \\
\text { Ukraine for 2021-2026" and "On approval of the Concept of implementation of the state policy of development of } \\
\text { Ukrainian e-infrastructures until } 2023 \text { and approval of the Action Plan"; } \\
\text { - Draft amendments to the Law "On Scientific and Scientific-Technical Expertise"; } \\
\text { - draft amendments to the Law "On Scientific and Scientific-Technical Activities" regarding the settlement of issues } \\
\text { related to the National Research Fund of Ukraine; } \\
\text { - draft resolution of the CMU "On amendments to the Model Regulations on the procedure for holding a } \\
\text { competition to fill vacant scientific positions of a state scientific institution"; } \\
\text { - draft resolution of the Cabinet of Ministers of Ukraine "On Amendments to the Resolution of the CMU of April } \\
\text { 14, } 2004 \text { № } 494 \text { " to ensure the implementation of the right of researchers to receive an allowance for research } \\
\text { experience }\end{array}$ \\
\hline
\end{tabular}




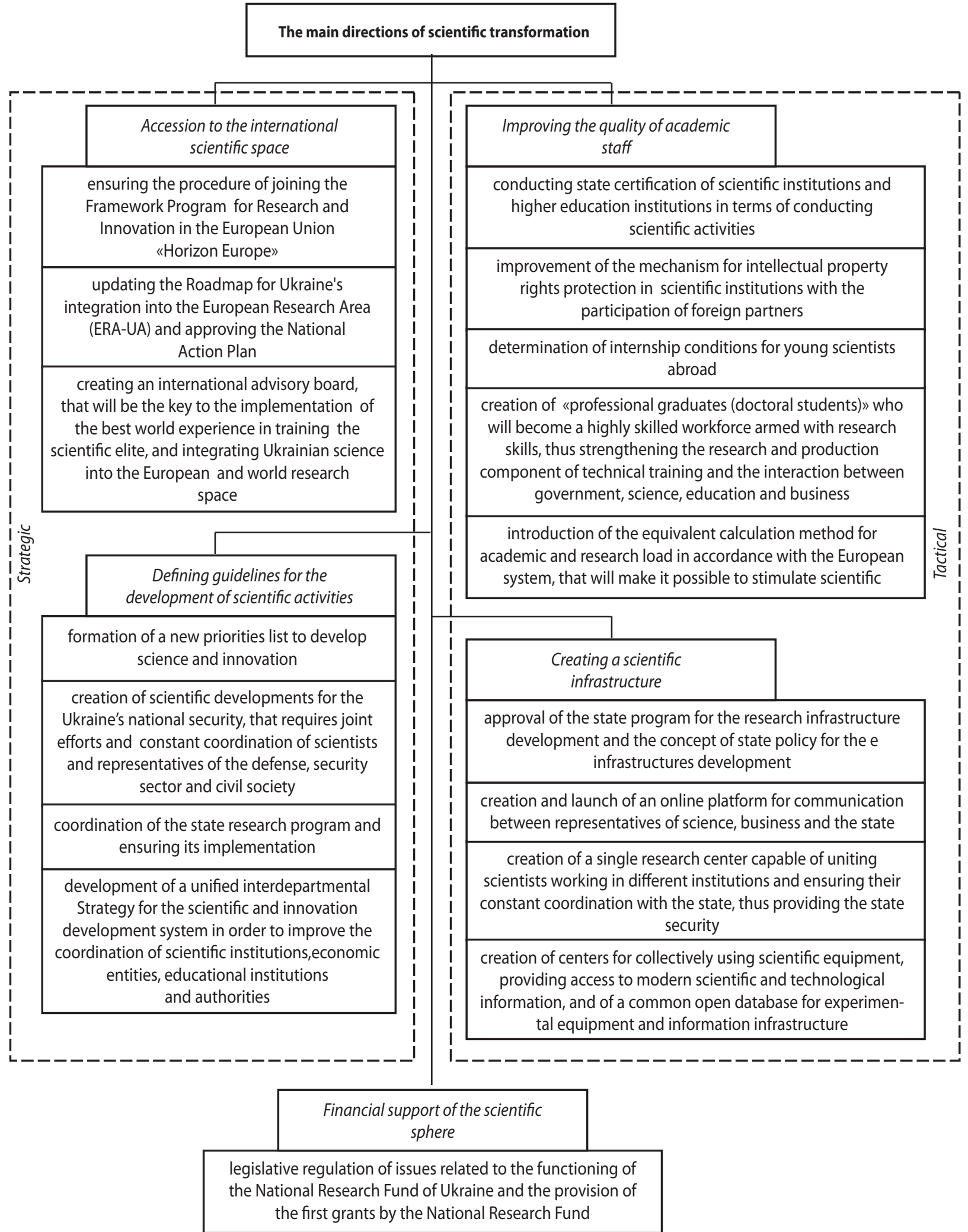

Fig. 2. The main directions of scientific transformations in Ukraine 


\begin{tabular}{|c|l|}
\hline 1 & \multicolumn{1}{c|}{ 2 } \\
\hline Scheduled & $\begin{array}{l}\text { draft Law "On the basic principles of formation and implementation of priority areas of scientific, scientific-technical } \\
\text { and innovative activities in Ukraine"; } \\
\text { draft amendment to the Law "On Scientific and Scientific-Technical Activity", in particular, on the application to the } \\
\text { definition of the term "young scientist" of the criterion of the number of years after obtaining a scientific degree "; } \\
\text { draft resolution of the CMU "On remuneration of managers, researchers and other employees who conduct scientific } \\
\text { and scientific-technical developments, institutions and institutions of science and education belonging to the } \\
\text { budget sphere" on the formation of new unified approaches to remuneration of researchers. }\end{array}$ \\
\hline
\end{tabular}

Ukrainian science system transformation is a priority of the state policy of the MES, that ensures identification of strategic points in developing education alongside with the provision of interaction between science, business and education. This is implemented by preparing strategic documents, guidelines and relevant state target programs (Fig. 3).

Reforming the scientific component of higher education is hampered by the imperfection of regulatory framework.

Successful implementation of the Ukrainian laws «On scientific and scientific and technological activities» [12] and «On higher education» [6] requires the introduction of many supplements and clarifications to these documents, that would regulate such points. The MES has both implemented and planned for the future activities aimed at ensuring trans- formational processes in education, science and innovation (Table 2).

Transformation occurs both at a university as a whole and in scientific activities, in particular. It is a process of radically changing the object as a whole or its individual elements due to the influence of external and internal factors. These processes are closely interconnected and take place at the same time, that is why we suggest to consider the following main stages of a university transformation in developing its scientific activity (Table 3).

The transformation includes changes in the emphasis in university management placed on scientific activities, goals and approaches to research, interaction with the authorities and stakeholders. According to the global trends in education,

Table 2

MES' results and goals in science and innovation

\begin{tabular}{|l|l|}
\hline \multicolumn{1}{|c|}{ MES' results } & \multicolumn{1}{c|}{ MES' goals } \\
\hline $\begin{array}{l}\text { Research programs have been approved and their } \\
\text { implementation has been ensured }\end{array}$ & $\begin{array}{l}\text { Approval of the Concept for the research infrastructures development in } \\
\text { Ukraine for 2021-2026 }\end{array}$ \\
\hline $\begin{array}{l}\text { The technological needs of the market and capabilities } \\
\text { of enterprises to use Ukrainian technologies have been } \\
\text { analyzed }\end{array}$ & $\begin{array}{l}\text { Creating an online platform for communication between participants in } \\
\text { the innovation process } \\
\text { ("Science and Business" platform) } \\
\text { Approval of the Concept for implementing the state policy for the } \\
\text { Ukrainian e-infrastructures development until 2023 and the action plan } \\
\text { for it }\end{array}$ \\
\hline $\begin{array}{l}\text { Evaluation of the efficiency of research institutions has } \\
\text { been provided. 224 research institutions have been } \\
\text { certified by the state }\end{array}$ & $\begin{array}{l}\text { Development of the Law of Ukraine "On the basic principles of formation } \\
\text { and implementation of priority areas of scientific, technological and } \\
\text { innovative activities in Ukraine" }\end{array}$ \\
$\begin{array}{l}\text { The work of the National Research Foundation (NRF) as a } \\
\text { source of independent grant funding was ensured and the } \\
\text { first competitive selection of research and development } \\
\text { projects was conducted by the Foundation }\end{array}$ & $\begin{array}{l}\text { Finalization of the bill "On Amendments to the Law of Ukraine "On } \\
\text { Scientific and Technological Expertise"' }\end{array}$ \\
\hline $\begin{array}{l}\text { Citizens' access to open data on scientific activity for } \\
\text { individual scientists, research institutions and higher } \\
\text { education institutions with state support has been } \\
\text { expanded }\end{array}$ & $\begin{array}{l}\text { Development and submission to the Government of legislative acts on } \\
\text { Ukraine's international cooperation with the EU and the United States } \\
\text { Ensuring integration into the European and global research space } \\
\text { and fulfillment of Ukraine's international obligations in scientific and } \\
\text { technological cooperation }\end{array}$ \\
\hline $\begin{array}{l}\text { Financing for research projects is provided at the expense } \\
\text { of the EU aid for Ukraine to fulfill its obligations under } \\
\text { "Horizon 2020", the EU Framework Program on Research } \\
\text { and Innovation }\end{array}$ & $\begin{array}{l}\text { Competitive selection of research and technological projects financed by } \\
\text { the EU for Ukraine to fulfill its obligations under "Horizon 2020", the EU } \\
\text { Framework Program for Research and Innovation }\end{array}$ \\
\hline
\end{tabular}

Source: compiled on [5] 


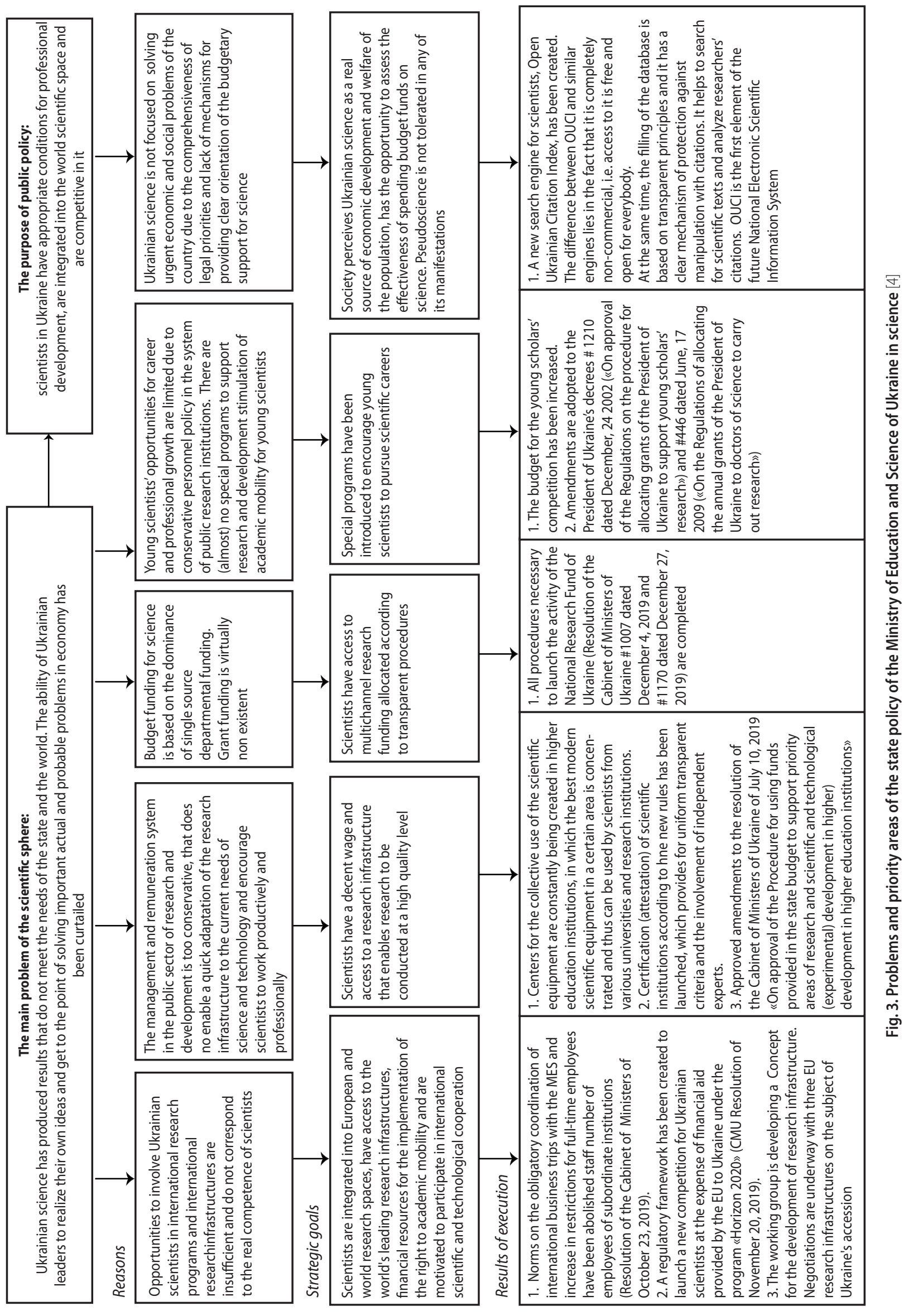




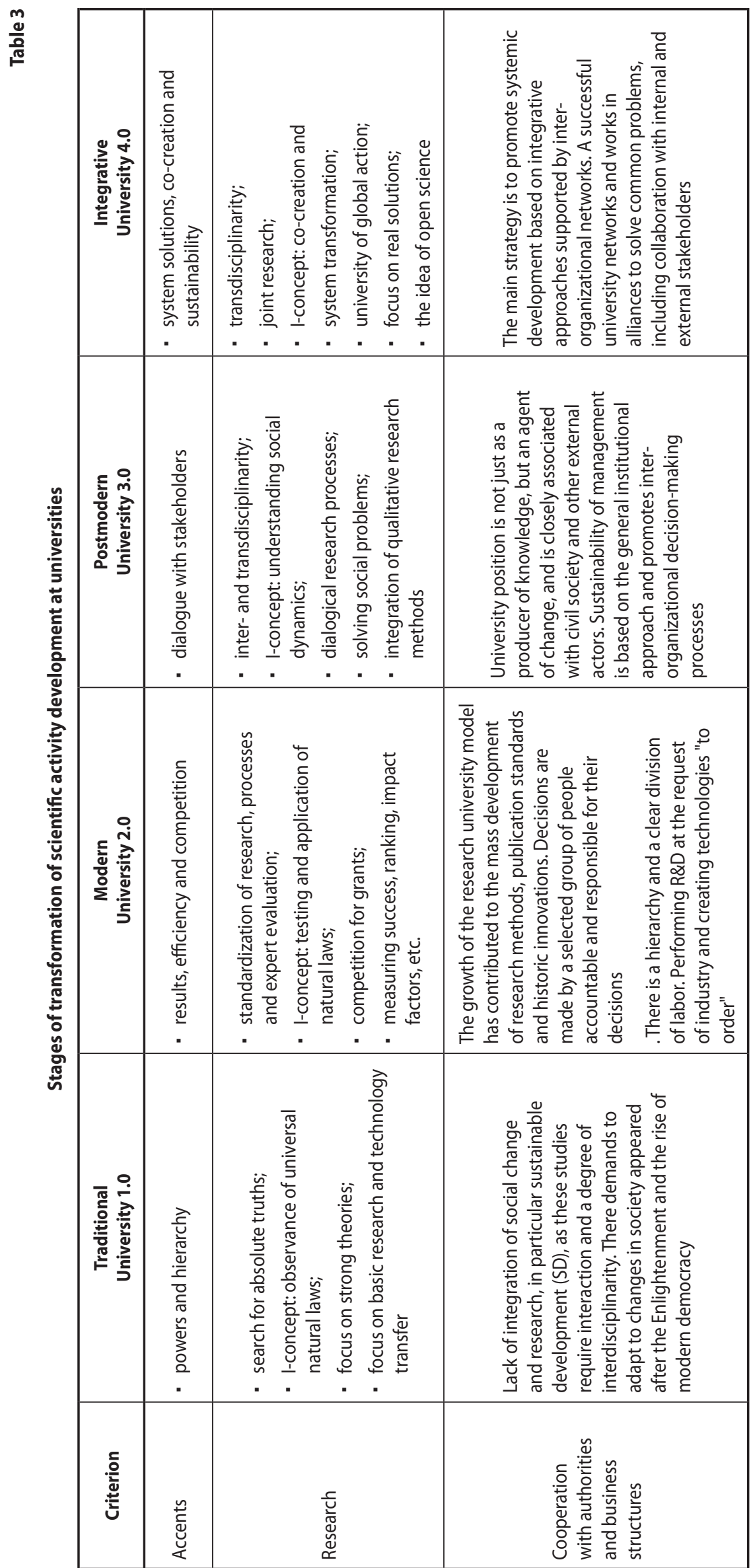


the processes of transforming scientific activities at a university are underway and contribute to innovation, economic growth, and solving major global problems. The main areas of strategic development of the world's leading universities are formed in their strategic documents, development programs, model decisions (Table 4).

Table 4

Trends in the transformation of scientific activities at universities

\begin{tabular}{|l|l|}
\hline \multicolumn{1}{|c|}{ Trend } & \multicolumn{1}{c|}{ Characteristic } \\
\hline $\begin{array}{l}\text { Creating digital strategic } \\
\text { partnerships }\end{array}$ & $\begin{array}{l}\text { Forming a global network of universities, corporations and scientific electronic space. Its purpose should } \\
\text { be to solve global problems and to set regional and national priorities }\end{array}$ \\
\hline Localization & $\begin{array}{l}\text { Strengthening regional ties with local communities, government and business structures emphasizes } \\
\text { the fact that the university will act as a community and develop in the region of its location. It provides } \\
\text { the promotion of regional joint projects, ensures that both the university and the region develop and } \\
\text { strengthen their cooperation in research and production }\end{array}$ \\
\hline $\begin{array}{l}\text { Growth of integrity and } \\
\text { practice-orientation }\end{array}$ & $\begin{array}{l}\text { Focus on the employer; integration of business, science, and education; collaboration of university } \\
\text { research and training with industry and business taken together consolidate the skills of goal } \\
\text { coordination, cooperation and coordination }\end{array}$ \\
\hline $\begin{array}{l}\text { Commercialization of } \\
\text { scientific ideas }\end{array}$ & $\begin{array}{l}\text { Technology transfer centers and technology parks at a university give students the opportunity to } \\
\text { organize startups and small firms to develop, patent and market technological products. Students create } \\
\text { jobs at the university, combining research with the educational process and business. Thus, there is a } \\
\text { gradual and predominant privatization of the university system by business, that is increasingly turning } \\
\text { scientific technology into a commercial commodity }\end{array}$ \\
\hline $\begin{array}{l}\text { Network integration into } \\
\text { the European system }\end{array}$ & $\begin{array}{l}\text { European DIHs (Digital Innovation Hubs) receive constant and huge support from their governments, } \\
\text { EU funds, as well as private business, have a developed and systematic brokerage of technology and } \\
\text { innovation, use a single information base, and provide support facilities for participants. } \\
\text { Support from the MES is needed in such areas as defining the model of innovation ecosystems, } \\
\text { determining their official status, searching for sponsors, integration into the DIH network, continuing } \\
\text { joint actions within the Innovation Forums, and other activities planned by the Ministry of Education and } \\
\text { Science. }\end{array}$ \\
\hline
\end{tabular}

Peculiarities of the university's scientific mission are conditioned by the ways of organizing research at the national (external-institutional) and university (internal-institutional) levels, i.e. by the peculiarities of scientific, technological and educational activities of an HEI, its structural subdivisions, and individual teachers. None of these models is ideal in modern conditions, as evidenced by the documents of higher education reforms that take place within further convergence of the European Higher Education Area and the European Research Area (Table 5).

Table 5

\section{Comparison of management features in scientific activity at research (entrepreneurial,} innovative) and educational universities

\begin{tabular}{|c|c|}
\hline Common features & Differences \\
\hline $\begin{array}{l}\text { - the structure of scientific activities is centralized and is carried out } \\
\text { mainly at the macro level of university management; } \\
\text { - the most developed are those management structures that provide } \\
\text { researchers with assistance in obtaining grants and other financial } \\
\text { support; } \\
\text { - the structure and distribution of functional responsibilities in the } \\
\text { teams of grant writers depend on the nature and scope of research } \\
\text { activity at the university }\end{array}$ & $\begin{array}{l}\text { - the structure of the scientific activities department at the } \\
\text { research university is more complex, which is determined } \\
\text { by the great variety and scope of tasks facing it; } \\
\text { - at the research university, the activities of the scientific } \\
\text { and other departments are promoting external funding } \\
\text { of research and the creation of a system of internal grants } \\
\text { mainly for young scholars }\end{array}$ \\
\hline
\end{tabular}

The efficiency of the management system of scientific activity at the modern university is a complex multifaceted function, that depends on many external and internal variables (Fig. 4).

The analysis of research at American universities [2] revealed the main trends in the transformation of scientific activities management, evolving in accordance with the rapid progress of society, economy, science, and technology. The effectiveness of scientific activities management, from the standpoint of sociology of management, is to transform the intellectual, material, organizational, financial and other resources of the university into specific results that have social significance and economic feasibility (Fig. 4, 5). 


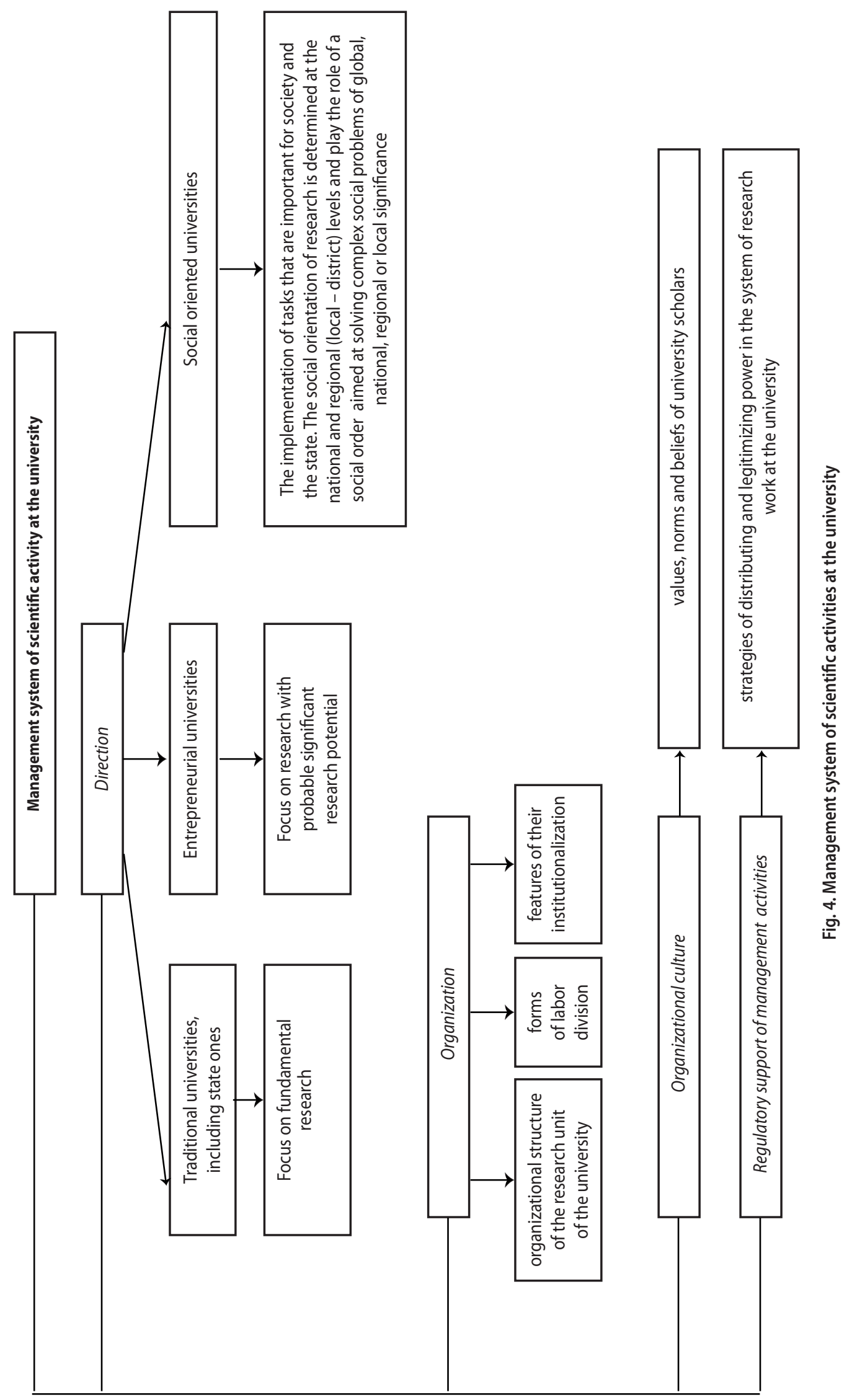



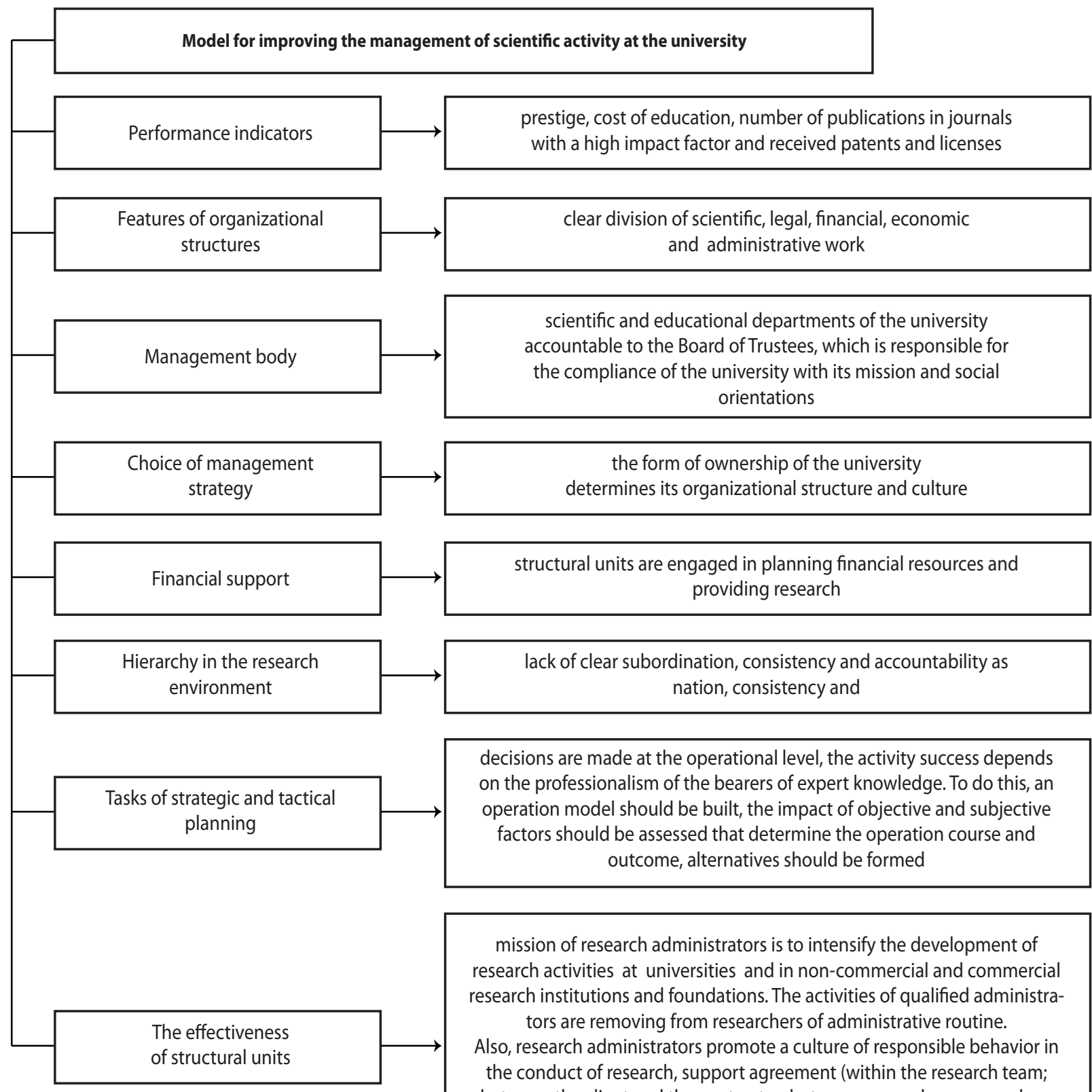

decisions are made at the operational level, the activity success depends on the professionalism of the bearers of expert knowledge. To do this, an operation model should be built, the impact of objective and subjective

factors should be assessed that determine the operation course and outcome, alternatives should be formed

mission of research administrators is to intensify the development of research activities at universities and in non-commercial and commercial research institutions and foundations. The activities of qualified administra-

tors are removing from researchers of administrative routine.

Also, research administrators promote a culture of responsible behavior in the conduct of research, support agreement (within the research team; between the client and the contractor; between researchers, researchers and regulatory agencies), promote the formation of public confidence in research activities and results

Fig. 5. Model for improving the management of scientific activity at the university

The effectiveness of the management of scientific and technological activities of the university, first of all, depends on cooperation between the university and industry and society, the latter determining the economic and social components of efficiency, and secondly, on the competence of research administrators and the work of scientists, administrators, teachers, etc. (Table 6).

Transformation of educational and scientific activities at the university includes such elements as reforming the system of state management of scientific activity in Ukraine, organization and redistribution of powers and responsibilities in order to increase the effectiveness of implementing socio-economic development priorities.
Conclusions. The areas of interaction between educational and scientific transformations in Ukraine are determined that will influence the development of Ukrainian science and its significant contribution to the country's economy due to its integration into the European Research Area. Recommendations for the educational and scientific activities at a university in Ukraine are based on a retrospective analysis of the existing concepts of scientific activities at a university, interaction with authorities and stakeholders, and management system providing for interaction between the educational and scientific activity at a university.

The application of public policy instruments in developed countries is aimed at attracting the potential of the sci- 
Areas for improving the management of the educational and scientific activities at the university

\begin{tabular}{|c|c|}
\hline Level & Measures \\
\hline Strategic level & $\begin{array}{l}\text { - To create a strategy for the research system development based on the analysis of the scientific potential of } \\
\text { the university staff and the needs of the region. } \\
\text { - To institutionalize research groups, including interdisciplinary ones, that have the potential to attract } \\
\text { external funding for research. } \\
\text { - To develop a portfolio of possible sponsors of research work that can be performed by university scientists. } \\
\text { - To create a system of internal grants to initially support forward-looking research. Develop fundraising } \\
\text { measures to support the internal grant system }\end{array}$ \\
\hline Administrative level & $\begin{array}{l}\text { - To train the members of the University Research Department to attract external research funding (from } \\
\text { agencies, organizations, foundations, individual donors, researchers and university staff who provide } \\
\text { organizational and financial services for projects) and organizational support of external grants. } \\
\text { - To develop the University strategy for the commercialization of intellectual property. To familiarize the } \\
\text { university staff with international achievements. } \\
\text { - To organize a self-government system of scientific activity for young scholars, aimed at finding additional } \\
\text { opportunities for young scholars' self-realization. } \\
\text { - To develop an effective model for evaluating the performance results of the University Research } \\
\text { - Department. } \\
\text { - To develop a system of indicators for evaluating the results of research activity at university departments. } \\
\text { university researchers and potential sponsors of their research activities }\end{array}$ \\
\hline
\end{tabular}

entific and educational sector to the commercialization of innovations and is due to the implementation of the concept of business universities. The development of cooperation within innovation ecosystems is stimulated by the introduction of the concept of open innovation platforms, that expands the possibilities of partnership based on research projects, stimulates the attraction of investors and accelerates research commercialization.

Acceleration of innovation and technological development and commercialization of innovations is actively implementing the concept of business universities that become centers of innovation development, as well as technological, human and entrepreneurial potential of the regions by developing and financing own business initiatives, joint projects with foreign investors, etc.

\section{LITERATURE}

1. de Weert E.(2004) The Organisational Determination of the Teaching and Research Nexus in the 2004 Marwell Conference Presentation at the Marwell 2004 Colloquium on Research and Teaching: closing the divide? URL: http://portallive.solent.ac.uk/ university/rtconference/2004/resources/de_weert_paper.pdf

2. Sbruieva A., Shykhnenko K. Student-Conducted Research in the Mission of the American Universities versus the Universities in Ukraine. Journal of History Culture and Art Research. 2020. Vol. 9 (4). P. 298-313.

DOI: $10.7596 /$ taksad.v9i4.2847

3. Звіт Міністерства освіти і науки України з виконання оперативного плану Міністерства освіти і науки України на 2020 рік та основні цілі на 2021 рік. URL: https://mon.gov.ua/ storage/app/media/rizne/2021/03.02.2021/ZVIT\%20MINISTER-
STVA\%20OSVITY\%20I\%20NAUKY\%20UKRAYINY\%20Z\%20VYKONANNYA\%20OPERATYVNOHO\%20PLANU.pdf

4. Перехідна книга МOH за період з вересня 2019 по березень 2020. URL: http://puet.edu.ua/sites/default/files/2020-0305_mon_perehidna_knyga_09.2019-03.2020.pdf

5. Пріоритети науково-технічної та інноваційної діяльності: триває перегляд законодавства. URL: https://Mon.Gov.Ua/ Ua/News/Prioriteti-Naukovo-Tehnichnoyi-Ta-Innovacijnoyi-Diyalnosti-Trivaye-Pereglyad-Zakonodavstva

6. Про вищу освіту : Закон України від 01.07.2014 № 1556VII. URL: https://zakon.rada.gov.ua/laws/show/1556-18\#Text

7. Про внесення змін до Положення про Національну раду України з питань розвитку науки і технологій : Постанова КМУ від 09.12.2020 № 1219. URL: https://zakon.rada.gov.ua/laws/ show/1219-2020-п\#Text

8. Про внесення змін до Порядку формування та використання коштів Національного фонду досліджень України : Постанова КМУ від 03.06.2020 № 443. URL: https://zakon.rada. gov.ua/laws/show/443-2020-п\#Text

9. Про внесення змін до постанов Кабінету Міністрів України від 04.07.2018 № 528 і від 04.12.2019 № 1007 : Постанова КМУ від 18.11.2020 № 1133. URL: https://zakon.rada.gov.ua/laws/ show/1133-2020-п\#Text

10. Про внесення змін до деяких законів України щодо активізації діяльності наукових парків : Закон України від 07.09.2021 № 1714-IX. URL: https://zakon.rada.gov.ua/laws/ show/1714-20\#Text

11. Про зміну складу Національної ради з питань розвитку науки і технологій : Розпорядження КМУ від 25.11.2020 № 1499-p. URL: https://www.kmu.gov.ua/npas/pro-zminu-skladunacionalnoyi-radi-z-pitan-rozvitku-nauki-i-tehnologij-i251120-1499

12. Про наукову і науково-технічну діяльність : Закон України від 25.12.2015 № 922-VIII. URL: https://zakon.rada.gov.ua/ laws/show/848-19\#Text 
13. Про цілі сталого розвитку України на період до 2030 року : Указ Президента України від 30.09.2019 № 722/2019. URL: https://zakon.rada.gov.ua/laws/show/722/2019\#Text

14. Реформа освіти та науки // Урядовий портал. URL: https://www.kmu.gov.ua/diyalnist/reformi/rozvitok-lyudskogokapitalu/reforma-osviti

15. Лозовий В. С. Реформування наукової сфери як чинник переведення економіки України на інноваційну модель розвитку : аналіт. записка // Національний інститут стратегічних досліджень. URL: https://niss.gov.ua/doslidzhennya/gumanitarniy-rozvitok/reformuvannya-naukovoi-sferi-yak-chinnik-perevedennya-ekonomiki

16. Сбруєва А. А. Управління науковою роботою в державних університетах США: структурно-функціональні аспекти. Порівняльно-педагогічні студії. 2010. № 1-2. С. 68-76.

DOI: 10.31499/2306-5532.1- 2.2010.18093

17. Спільна декларація міністрів освіти Європи «Європейський простір у сфері вищої освіти» від 19.06.1999р. URL: https://zakon.rada.gov.ua/laws/show/994_525\#Text

\section{REFERENCES}

[Legal Act of Ukraine] (1999). https://zakon.rada.gov.ua/ laws/show/994 525\#Text

[Legal Act of Ukraine] (2014). https://zakon.rada.gov.ua/ laws/show/1556-18\#Text

[Legal Act of Ukraine] (2015). https://zakon.rada.gov.ua/ laws/show/848-19\#Text

[Legal Act of Ukraine] (2019). https://zakon.rada.gov.ua/ laws/show/722/2019\#Text

[Legal Act of Ukraine] (2020). https://www.kmu.gov.ua/ npas/pro-zminu-skladu-nacionalnoyi-radi-z-pitan-rozvitku-naukii-tehnologij-i251120-1499

[Legal Act of Ukraine] (2020). https://zakon.rada.gov.ua/ laws/show/1219-2020-п\#Text

[Legal Act of Ukraine] (2020). https://zakon.rada.gov.ua/ laws/show/443-2020-п\#Text

[Legal Act of Ukraine] (2020). https://zakon.rada.gov.ua/ laws/show/1133-2020-п\#Text

[Legal Act of Ukraine] (2021). https://zakon.rada.gov.ua/ laws/show/1714-20\#Text

Lozovyi, V. S. "Reformuvannia naukovoi sfery yak chynnyk perevedennia ekonomiky Ukrainy na innovatsiinu model rozvytku: analit. zapyska" [Reforming the Scientific Sphere as a Factor in the
Transition of Ukraine's Economy to an Innovative Model of Development: An Analytical Note]. Natsionalnyi instytut stratehichnykh doslidzhen. https://niss.gov.ua/doslidzhennya/gumanitarniy-rozvitok/reformuvannya-naukovoi-sferi-yak-chinnik-perevedennyaekonomiki

"Perekhidna knyha MON za period z veresnia 2019 po berezen 2020" [Transitional Book of the Ministry of Education and Science for the Period from September 2019 to March 2020]. http:// puet.edu.ua/sites/default/files/2020-03-05_mon_perehidna_ knyga_09.2019-03.2020.pdf

"Priorytety naukovo-tekhnichnoi ta innovatsiinoi diialnosti: tryvaie perehliad zakonodavstva" [Priorities of Scientific, Technical and Innovative Activities: Review of Legislation Is Underway]. https://Mon.Gov.Ua/Ua/News/Prioriteti-Naukovo-Tehnichnoyi-TaInnovacijnoyi-Diyalnosti-Trivaye-Pereglyad-Zakonodavstva

"Reforma osvity ta nauky" [Education and Science Reform]. Uriadovyi portal. https://www.kmu.gov.ua/diyalnist/reformi/rozvitok-lyudskogo-kapitalu/reforma-osviti

Sbruieva, A. A. "Upravlinnia naukovoiu robotoiu v derzhavnykh universytetakh SShA: strukturno-funktsionalni aspekty" [Management of Research at US Public Universities: Structural and Functional Aspects]. Porivnialno-pedahohichni studii, no. 1-2 (2010): 68-76.

DOI: 10.31499/2306-5532.1- 2.2010.18093

Sbruieva, A., and Shykhnenko, K. "Student-Conducted Research in the Mission of the American Universities versus the Universities in Ukraine". Journal of History Culture and Art Research, vol. 9 (4) (2020): 298-313.

DOI: $10.7596 /$ taksad.v9i4.2847

de Weert, E. "The Organisational Determination of the Teaching and Research Nexus in the 2004 Marwell Conference Presentation at the Marwell 2004 Colloquium on Research and Teaching: closing the divide?" http://portallive.solent.ac.uk/university/ rtconference/2004/resources/de_weert_paper.pdf

"Zvit Ministerstva osvity i nauky Ukrainy z vykonannia operatyvnoho planu Ministerstva osvity i nauky Ukrainy na 2020 rik ta osnovni tsili na 2021 rik" [Report of the Ministry of Education and Science of Ukraine on the Implementation of the Operational Plan of the Ministry of Education and Science of Ukraine for 2020 and the Main Goals for 2021]. https://mon.gov.ua/storage/app/media/ rizne/2021/03.02.2021/ZVIT\%20MINISTERSTVA\%200SVITY\%20 I\%20NAUKY\%20UKRAYINY\%20Z\%20VYKONANNYA\%20OPERATYVNOHO\%2OPLANU.pdf

Стаття надійшла до редакції 08.11.2021 р. 